\title{
Inhibition of Platelet Aggregation by Rat Trophoblasts
}

\author{
R. Tewaria M.P. Singh ${ }^{b}$ S. Farheen ${ }^{a} \quad$ M. Dikshitb P.K. Mehrotra ${ }^{a}$ \\ Divisions of aEndocrinology and bPharmacology, Central Drug Research Institute, Lucknow, India
}

\section{Key Words}

Rat trophoblasts · Embryonic cells · Thrombocytes

\begin{abstract}
Objective: To determine the effect of rat trophoblast cell suspensions on adenosine diphosphate (ADP)-induced platelet aggregation. Materials and Methods: The trophoblasts were isolated from ectoplacental cones (a preplacental tissue very rich in trophoblasts) developed in rat embryos on day 12 of pregnancy (normal period of gestation: 22-23 days). Platelet-rich plasma (PRP) was obtained from adult male rats. The trophoblasts were preincubated $\left(37^{\circ} \mathrm{C}, 30 \mathrm{~min}\right)$, suspended in the medium, and then re-incubated with PRP for 3-5 min. Results: $5 \times$ $10^{4}$ and $7 \times 10^{4}$ trophoblasts inhibited ADP-induced platelet aggregation by 10 and $18 \%$, respectively. When the trophoblast cell concentration was increased to 1$2 \times 10^{5}$ cells, a proaggregatory phenomenon was observed, even in the absence of ADP. However, there was no inhibition of aggregation or promotion of aggregation when fixed trophoblasts or live endometrial stromal cells were incubated with PRP. Conclusion: The results indicate that the aggregation inhibition response was cell specific and concentration dependent. A $68-\mathrm{kD}$ protein
\end{abstract}

was detected in the medium when it was conditioned with 5-7 $\times 10^{4}$ but not with $1-2 \times 10^{5}$ trophoblasts. However, the inhibitory or stimulatory effect does not seem to be dependent on the presence of this protein.

Copyright $\odot 2002$ S. Karger AG, Basel

\section{Introduction}

In most of the rodent species, as trophoblasts begin to attach to the receptive uterine epithelium during implantation, the uterus clamps around the blastocyst. Thereafter, the following remarkable events take place sequentially: transepithelial invasion of trophoblasts, transformation of uterine stroma, recruitment of inflammatory and endothelial cells into the endometrium and apoptosis of uterine epithelial cells. Thus, implantation is a highly coordinated process in which specialized cells of the outer layer of the embryo, the trophoblasts, establish contacts with highly sensitized luminal epithelial cells. Coordination between the two alien types of cells involves regulatory production of proteolytic enzymes, growth factors, cytokines and hormones. Additionally, the cell surface components also become functionally available to support attachment of trophoblasts and uterine cells.

\begin{tabular}{ll}
\hline KARGER & ( 2002 S. Karger AG, Basel \\
Fax +4161306 1234 & 1011-7571/02/0112-0100\$18.50/0 \\
$\begin{array}{l}\text { E-Mail karger@karger.ch } \\
\text { www.karger.com }\end{array}$ & $\begin{array}{l}\text { Accessible online at: } \\
\text { www.karger.com/journals/mpp }\end{array}$
\end{tabular}

P.K. Mehrotra, PhD

Division of Endocrinology, Central Drug Research Institute

PO Box 173, Lucknow 226001 (India)

Tel. +91 522212411418 (PABX 4246 ext.), Fax +91 522 223405/223938/229504

E-Mail purshottam123@rediffmail.com 
Later acquisitions in the embryo and the uterus include differentiation and ordered activation of gene expression, programmed changes of mRNA and protein of the uterine cells as well as the expression of extracellular matrix (ECM) receptors and matrix-degrading activities in the trophoblasts that augment their invasion through the endometrium [1]. In addition to these activities, extensive changes occur in the endometrial vascular architecture, resulting in increased blood flow at the site of preplacental development [1].

The trophoblasts contain a large number of secondary lysosomes and phagosomes, which exhibit strong phagocytic activity. This activity includes engulfment not only of necrosing endometrial epithelial and stromal cells but also cells of lymphopoietic origin [2-4]. As the phagocytic activity of trophoblasts is a continuous process, it leads to the formation of large sinuses in the mesometrial region in which the maternal blood flows for the nourishment of the developing placenta and the embryo. Whether the unrestricted flow is due to inhibition of platelet aggregation caused by the proliferating trophoblasts or the differentiated endometrial stromal cells is not known.

Earlier studies assumed that pre- and peri-implantation embryos released platelet-activating factor (PAF) [5]. Many other cells including neutrophils, monocytes, macrophages, endothelial and smooth muscle cells also produce PAF. Therefore the release of PAF is not necessarily a specific action of only pre- and peri-implantation embryos [6]. Moreover, PAF is also known to act as an autocoid. Further, significant thrombocytopenia is also reported to occur during pre- and peri-implantation phase of embryonic development [7]. The phenomenon is augmented in the presence of a zygote since the injection of the conditioned media that contained a chemical signal homologous to PAF has been found to promote this phenomenon [8]. However, the direct involvement of PAF in platelet aggregation (promotion or inhibition) has not been supported by more recent studies [9].

In another study, O'Neill [10] showed that trophoblasts proliferated more in the presence of plateletderived growth factor (PDGF) and were dependent on the platelet count as this phenomenon was observed only in platelet-rich plasma (PRP). Whether or not the PDGFinduced trophoblast outgrowth can be linked with platelet aggregation phenomena is difficult to say at present. Since no information is available in the literature on platelet aggregation, the present study was carried out to examine the effect of trophoplast and stromal cells on the aggregation of platelets.

Platelet Aggregation and Trophoblasts

\section{Materials and Methods}

\section{Trophoblasts}

Adult Sprague-Dawley female rats (150-200 g) from the Central Drug Research Institute, Lucknow, India, were used. Virgin females at proestrus were mated with males (in 2:1 ratio) overnight in a plastic cage. Vaginal smears were examined the following morning for confirmation of mating. This day was considered as day 1 postcoitum (p.c.). Sperm-positive animals were sacrificed on day 12 p.c. and the uterine horns containing implantations were excised and placed in Hanks' balanced salt solution (HBSS).

From each implant the decidual swellings were taken out after removing serosa and myometrial coverings (by cutting the entire horn longitudinally) and floated in buffer. Each swelling was cut sagittally into two halves by a sharp-edged scalpel. The embryo (lying in one half) was scrapped carefully with a needle, washed in buffer, and then transferred to a glass cuvette (15 $\mathrm{mm}$ in diameter) containing HBSS, using a glass microcapillary attached to a hand-operated micromanipulator (Assistent Micro-Pipex, No. 558, Lapine Scientific Co., Germany). The embryo has a red cap-like structure (visible under the stereo binocular), very rich in trophoblasts, designated as the ectoplacental cone (EPC). The EPCs were separated by sharply pointed microneedles and then teased into minute fragments, processed for isolation of trophoblast cells according to a method described earlier [11]. Finally, the pellet containing the homogeneous colony of trophoblasts was suspended in $0.5 \mathrm{ml}$ Dulbecco's Modified Eagle's Medium (DMEM). Prior to reacting with PRP, the number of cells was counted in a hemocytometer. Cell viability was checked by the trypan blue dye exclusion method [12] and only when the number of viable cells exceeded $90 \%$ were then used for the study.

Isolated trophoblasts were transferred to a tube containing $1 \%$ paraformaldehyde solution and kept for $10 \mathrm{~min}$. After fixation, the cell suspension was centrifuged, and the resultant pellet containing fixed cells was suspended in HBSS.

\section{Decidual Cells}

The remaining halves of the swellings (after removing the egg cylinder) were washed in fresh culture medium (M-199) and then minced into minute pieces $\left(0.1 \mathrm{~mm}^{2}\right)$. These pieces were exposed to collagenase $(5.0 \mathrm{mg}$ in $3.0 \mathrm{ml}$ medium) in a $10.0-\mathrm{ml}$ conical flask placed on a Dubnoff metabolic shaker $\left(37^{\circ} \mathrm{C}\right)$ to isolate decidual cells according to a method described earlier [13]. Cell viability was assessed and total cell counts were performed on a hemocytometer. The total cell count was $3.86 \times 10^{6} / \mathrm{ml}$. All the biochemicals were procured from Sigma, St. Louis, USA.

\section{Platelet-Rich Plasma}

Blood was collected by cardiac puncture from male SpragueDawley rats (135-150 g), anaesthetized with ether (hydroquinone, $0.00018 \% \mathrm{w} / \mathrm{v}$, TKM Pharma, Hyderabad, India) and placed into sodium citrate $(3.8 \% \mathrm{w} / \mathrm{v}, 9: 1 \mathrm{v} / \mathrm{v})$-pretreated tubes. The citrated blood was centrifuged at $180 \mathrm{~g}$ for $20 \mathrm{~min}\left(\right.$ at $20^{\circ} \mathrm{C}$ ) to separate PRP.

\section{Platelet Aggregation}

The PRP $\left(400 \mu 1,1 \times 10^{8}\right.$ cells $)$ was preincubated with the trophoblast cell suspensions $\left(1 \times 10^{4}-1 \times 10^{6}\right)$ in a volume of $100 \mu \mathrm{l}$ buffer or the suspension media (DMEM or HBSS) at $37^{\circ} \mathrm{C}$ for $3-$ $5 \mathrm{~min}$. Platelet aggregation was induced by adenosine $5^{\prime}$-diphosphate (ADP; 2.0-6.5 $\mu M$ ) and monitored in a dual-channel aggregometer (model 560; Chronolog Corporation, Havertown, Pa., USA) with 


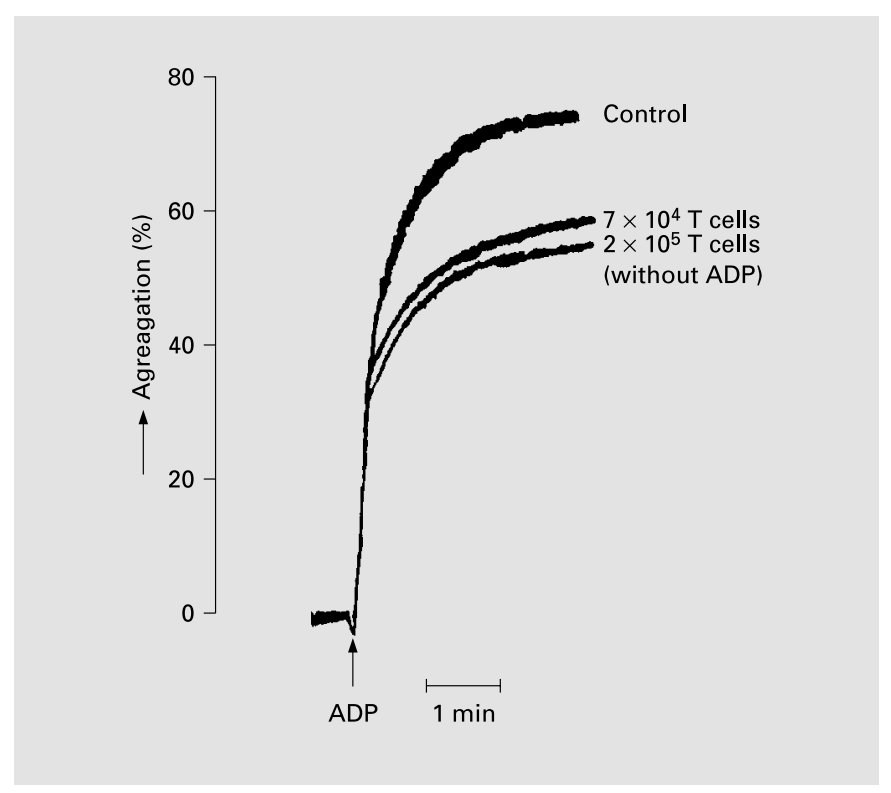

Fig. 1. Effect of rat trophoblasts on ADP $(2.0-6.5 \mu M)$ induced platelet aggregation phenomenon. ADP was added to the platelet rich plasma pretreated with trophoblast cells. At the $7 \times 10^{4}$ cell concentration, a significant inhibition was observed. However, in the presence of $2 \times 10^{5}$ cells, the aggregation of platelets was seen even without addition of ADP.

continuous stirring at $700 \mathrm{rpm}$ [14]. The data were recorded on a chart recorder (Model 707, Chronolog Corporation). The difference in light transmission between PRP and the suspension media was designated as $100 \%$ and was used to calculate the percent aggregation. The live trophoblast cell suspension at various concentrations, the live decidual cell suspension $\left(3.86 \times 10^{6}\right)$, and the fixed trophoblast cell suspensions $\left(2 \times 10^{4}-10^{5}\right)$ were added to either PRP or the suspension media and the platelet aggregation response was monitored.

Statistical significance was determined by using ANOVA and Student's t test. Values reported are means \pm SE. The difference between the two groups was considered significant at $\mathrm{p}<0.01$.

\section{Analysis of Trophoblast-Cell-Conditioned Media}

The trophoblast cells, in the concentrations at which they inhibited platelet aggregation, were seeded in a round culture dish $(35 \mathrm{~mm}$; Nunc, Denmark) containing DMEM complemented with 10\% FCS. The dish was placed in a humidified $\mathrm{CO}_{2}$ incubator (Forma Scientific Co., USA). After $24 \mathrm{~h}$, when the cells settled and began to grow, the complemented medium was replaced by medium without complement. The culture was continued for $48 \mathrm{~h}$ after which complete confluency was observed. The conditioned medium was collected in a tube and ultracentrifuged to remove debris and/or any contaminants. The medium was then extensively dialysed to remove interfering salts and stored in lyophilized form at $-20^{\circ} \mathrm{C}$ before analysis by single-dimension gel electrophoresis. The protein content in the reconstituted pellet of the conditioned medium was estimated according to Bradford [15].

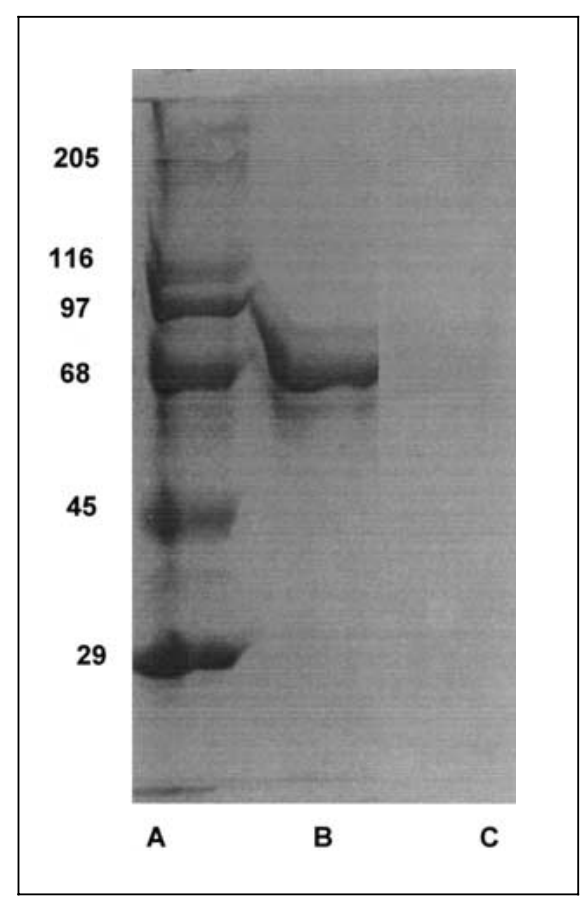

Fig. 2. SDS-PAGE of trophoblast cell-conditioned medium in rat.

\section{Results}

The ADP $(2.0-6.5 \mu M)$-induced platelet aggregation in the presence of medium without trophoblast cells was 78 $\pm 2 \%$ (fig. 1). The addition of two different concentrations of trophoblasts $\left(5 \times 10^{4}\right.$, and $7 \times 10^{4}$ cells $)$ to the PRP did not produce any change (vs. control, $p>0.05$ ), but decreased the ADP-induced platelet aggregation response to $69 \pm 1 \%$ and $60 \pm 3 \%$, respectively (vs. control, $\mathrm{p}<0.01$ ) (table 1). However, when the trophoblast cell number was increased to $1-2 \times 10^{5}$, the cell suspension itself produced a platelet aggregation response (57 \pm $7 \%)$ even in the absence of ADP. The addition of $2 \times 10^{4}$ trophoblast cells to PRP, however, had no effect on ADPinduced platelet aggregation. Fixed trophoblast cells $(2 \times$ $10^{4}-2 \times 10^{5}$ cells) also had no effect on ADP-induced aggregation response. Similarly, the endometrial stromal (decidual) cells of corresponding gestational age did not have any effect on the aggregation response.

The analysis of trophoblast-cell-conditioned media (5$7 \times 10^{4}$ concentrations) on gel electrophoresis revealed a major protein band at $68 \mathrm{kD}$ and a minor one at approximately $60 \mathrm{kD}$. These bands were, however, absent when the medium conditioned with $1-2 \times 10^{4}$ cell concentra- 
Table 1. ADP-induced platelet aggregation response in the presence and absence of trophoblast cells

\begin{tabular}{lllll}
\hline Cells & $\begin{array}{l}\text { Platelet } \\
\text { aggregation } \\
\text { mean } \pm \text { SE }\end{array}$ & Observations & $\begin{array}{l}\text { Inhibition } \\
\%\end{array}$ & p value $^{\mathrm{a}}$ \\
\hline Control & $78 \pm 2$ & 11 & - & \\
$2 \times 10^{4}$ & $77 \pm 3$ & 3 & 1 & $\mathrm{NS}$ \\
$5 \times 10^{4}$ & $69 \pm 1^{\mathrm{a}}$ & 3 & 12 & $<0.01$ \\
$7 \times 10^{4}$ & $60 \pm 3^{\mathrm{a}}$ & 4 & 23 & $<0.01$ \\
$\begin{array}{l}1-2 \times 10^{5} \\
\quad(\text { without ADP) }\end{array}$ & $57 \pm 7$ & 9 & $\mathrm{NA}$ & $\mathrm{NS}$ \\
$\begin{array}{c}\text { Fixed cells } \\
\left(2 \pm 10^{4}-2 \times 10^{5}\right)\end{array}$ & $77 \pm 4$ & 3 & 1 & $\mathrm{NS}$ \\
$\begin{array}{c}\text { Decidual cells } \\
\left(2 \times 10^{4}-2 \times 10^{5}\right)\end{array}$ & $76 \pm 4$ & 2 & 3 & $\mathrm{NS}$ \\
\hline
\end{tabular}

$\mathrm{NA}=$ Not applicable; $\mathrm{NS}=$ not significant.

$\mathrm{p}<0.01$ highly significant, compared to control. tions was loaded on the gel (fig. 2). The media conditioned with trophoblasts at 5-7 $\times 10^{4}$ cell numbers also failed to produce any inhibitory response (as compared to the trophoblasts at these cell numbers in suspension).

\section{Discussion}

Results of the present study reveal that the rat trophoblasts did not affect ADP-induced platelet aggregation at a lower cell number $\left(2 \times 10^{4}\right)$, but inhibited aggregation significantly $(\mathrm{p}<0.01)$ when used at slightly higher cell numbers (between $5 \times 10^{4}$ and $7 \times 10^{4}$ cells) suspended in medium or buffer. However, cell numbers above $7 \times$ $10^{4}$ and up to $1-2 \times 10^{5}$ did not show any inhibitory response. Rather, a proaggregatory response (even in the absence of ADP) was noticed.

The results, though enigmatic, are quite interesting. On the one had, a low range of cell concentrations showed an inhibitory response, whereas a higher range of cell concentrations did not. One explanation for these results is that during early embryonic development and placental morphogenesis, the trophoblast cells encroach upon the space left by phagocytosis of endometrial cells in the mesometrial region. Once the placenta is formed and the embryo is fully anchored, the invading process is checked by the cells of differentiated endometrium known as decidua. The trophoblasts may then go into a resting stage, where probably no further proliferation takes place. Thus, when the numbers of trophoblasts are moderate $\left(5-7 \times 10^{4}\right)$, as observed in this study, the cells are in a proliferating state, necessitating an uninterrupted flow of blood. However, once the placenta is established, and the number of cells increased $\left(1-2 \times 10^{5}\right)$, the possibility of platelet aggregation increases, enabling the pregnancy to be fully sustained.

The above explanation is consistent with reports showing that during early gestation, when the number of trophoblast cells are low and the level of adenosine is high, there is less platelet aggregation [16, 17]. However, during late gestation, when the numbers of trophoblast cells are very high, the adenosine level becomes very low due to the elevation of the enzyme adenosine deaminase [18]. Consequently, the inhibitory response of adenosine is decreased and the proaggregatory response occurs due to the absence of adenosine.

The decidual cell suspension, on the contrary, did not show any effect on aggregation, indicating that the inhibition of platelet aggregation during early pregnancy was caused by trophoblast cells only.

On analysis of day 12 trophoblast-conditioned medium, a $68-\mathrm{kD}$ protein was isolated which, we assumed, might be mediating inhibition or stimulation of platelet aggregation depending on the number of cells, vis-à-vis the concentration of the protein. We speculated that this protein was believed to be synthesized intracellulary because there was no response in the medium containing fixed trophoblast cells (table 1). However, since we did not observe any change in platelet aggregation by the trophoblast-conditioned medium, the protein appears not to 
be secretory but labile and is released after cell-to-cell interaction of trophoblasts and platelets. This protein does not appear to be related to PAF because PAF is reported to induce thrombocytopenia during the pre- and peri-implantation phases of pregnancy [8].

From these findings, it may thus be inferred that midgestation rat trophoblasts secrete some substance which inhibits platelet aggregation. The inhibitory response is, however, dependent on cell density. This is the first in vitro study to our knowledge reporting the presence or appearance of PAF in the trophoblasts during invasion of the endometrium in early pregnancy. However, the nature of this factor is yet to be established. In vitro studies are, however, not a replica of events in vivo.

\section{Conclusion}

On day 12 of gestation of a rat embryo, the inhibition response to platelet aggregation was cell specific and concentration dependent. A $68-\mathrm{kD}$ protein was detected in a trophoblast-conditioned medium at concentrations of 5$7 \times 10^{4}$ cells but not at $1-2 \times 10^{5}$ cells. The inhibitory or stimulatory effect of platelet aggregation does not seem to be dependent on the presence of this protein.

\section{Acknowledgement}

The authors are thankful to Dr. C.M. Gupta, Director, Central Drug Research Institute, Lucknow, for showing keen interest and to Mr. S.A.V. Raghavan for assistance in the study. The funds were provided by the Ministry of Health and Family Welfare, Government of India.

\section{References}

1 Carson DD, Bagchi I, Dey SK, Enders AC, Fazleabas AT, Lessey BA, Yoshinaga K: Embryo implantation (Review). Dev Biol 2000;223: 217-237.

2 Kirby DRS: Blastocyst uterine relationship before and during implantation; in Blandau RJ (ed): The Biology of the Blastocyst. Chicago, Chicago University Press, 1971, pp 393-419.

3 Mehrotra PK: Ultrastructure of mouse ectoplacental cone cells. Biol Struct Morphol 1988;1: 63-68.

4 Nieder GL, Caprio TL: Early embryo development in Siberian hamster (Phodopus sungorus). Molec Reprod Dev 1990;27:224-229.

5 O'Neill C: Examination of the causes of early pregnancy associated thrombocytopenia in mice. J Reprod Fertil 1985;73:578-585.

6 Braquet P, Touqui L, Shen TY, Vargaftig BB: Perspectives in platelet activating factor research. Pharmacol Rev 1987;39:97-145.

7 O'Neill C: Embryo-derived platelet activating factor: A pre-implantation embryo mediator of maternal recognition of pregnancy. Domest Anim Endocrinol 1987;4:69-86.
8 Collier M, O'Neill C, Ammit AJ, Saunders DM: Biochemical and pharmacological characterization of human embryo-derived platelet activating factor. Hum Reprod 1988:3:993998.

9 O’Neill C, Ryan JP, Collier M, Saunders DM, Ammit AJ, Pike IL: The outcome of pregnancies resulting from a trial of supplementing human IVF culture media with platelet activating factor. Reprod Fertil Dev 1992;4:109-112.

10 O'Neill C: The role of blood platelets in the establishment of pregnancy; in Hau $\mathrm{J}$ (ed): Pregnancy Proteins in Animals. Berlin, de Gruyter, 1986, pp 225-234.

11 Pande S, Shukla R, Mehrotra PK, Kamboj VP: Isolation and culture of hamster ectoplacental cone trophoblasts: An in vitro study on the cell types and their growth pattern. Cell Prolif 1996;29:163-171.

12 Philips HJ: Evaluation of culture dynamics; dye inclusion test for cell viability; in Cruse PF, Patterson MK (eds): Tissue Culture: Methods and Application. London, Academic Press, 1973, pp 406-419.

13 Pande S, Malaviya B, Mehrotra PK, Kamboj VP: Determination of proteins secreted by growing rat decidual cells in vitro. Indian J Exp Biol 1996;34:1100-1103.
14 Dikshit M, Kumari R, Srimal RC: Pulmonary thromboembolism-induced alterations in nitric oxide release from rat circulating neutrophils. J Pharmacol Exp Ther 1993;265:1269-1274.

15 Bradford MM: A rapid and sensitive method for the quantitation of microgram quantities of protein utilizing the principle of protein-dye binding. Analyt Biochem 1976;72:248-254.

16 Zatta A, Pandolfo L, Caparrotta L, Prosdocimi M, Dejana E, Del Maschio A: Platelet aggregation induced by the endoperoxide analogue U46619 is inhibited by polymorphonuclear leukocyte ADPase activity. Arterioscler Thromb 1993;13:696-701.

17 Blackburn MR, Gao X, Airhart MJ, Skalko RG, Thompson LF, Knudsen TB: Adenosine levels in the post implantation mouse uterus: Quantitation by HPLC-fluorometric detection and spatiotemporal regulation by 5 -nucleotidase and adenosine deaminase. Dev Dyn 1992; 194:155-168.

18 Hong L, Mulholland J, Chinsky JM, Knudsen TB, Kellems KE, Glasser SR: Developmental expression of adenosine deaminase during decidualization in the rat uterus. Biol Reprod 1991;44:83-93. 